\title{
“Menghidupkan” Undang-Undang Dasar 1945 Tanpa Amandemen
}

\author{
Wira Atma Hajri dan Rahdiansyah \\ Program Studi Ilmu Hukum Fakultas Hukum Universitas Islam Riau \\ Jl. Kaharuddin Nasution No. 113 Perhentian Marpoyan Pekanbaru-Riau \\ w.a.hajri@law.uir.ac.id; rahdiansyah@law.uir.ac.id
}

Received: 11 Desember 2017; Accepted: 9 April 2018; Published: 5 Juni 2018

DOI: 10.20885 /iustum.vol24.iss4.art3

\begin{abstract}
This study examined why the Fifth Amendment of the 1945 Constitution was difficult and examined other ways to make the 1945 Constitution as a constitution that is living without any formal procedures. This was a normative legal study using statute, conceptual, sociological, political, and historical approaches. The findings indicated that the difficulty of reviving the 1945 Constitution through the Fifth Amendment is due the fact that the formal procedure for the amendment of the 1945 Constitution was rigid, the Fifth Amendment did not receive any political support, and the momentum of the amendment was not appropriate. Nevertheless, there are other possible ways to make the 1945 Constitution as a living constitution, i.e. through arrangement in legislations, through the interpretation of constitutional justices, and through constitutional convention.
\end{abstract}

Keywords: Amendement; living constitution; interpretation constitution

Abstrak

Penelitian ini mengkaji tentang penyebab sulitnya amendemen kelima UUD 1945 dan mengkaji cara lain untuk mewujudkan UUD 1945 sebagai konstitusi yang hidup tanpa melalui prosedur formal. Penelitian ini adalah penelitian hukum normatif dengan menggunakan pendekatan peraturan perundang-undangan, konsep, sosiologis, politik, dan pendekatan sejarah. Hasil penelitian ini menunjukkan bahwa sulitnya menghidupkan UUD 1945 melalui amendemen kelima dikarenakan prosedur formal perubahan UUD 1945 yang terlalu rigid, amendemen kelima tidak mendapatkan dukungan politik, dan persoalan momentum yang belum tepat. Kendatipun demikian, ada cara lain yang dapat ditempuh untuk mewujudkan UUD 1945 sebagai konstitusi hidup yaitu melalui pengaturan di dalam undang-undang, melalui interpretasi hakim konstitusi, dan melalui konvensi ketatanegaraan.

Kata-kata Kunci: Amendemen; konstitusi hidup; penafsiran konstitusi 


\section{Pendahuluan}

Harus diakui bahwa amendemen UUD 1945 pada 1999, 2000, 2001, dan 2002 lalu, tidak terlepas dari kelemahan-kelemahan. HAS. Natabaya mengatakan bahwa hasil amendemen tersebut adalah "cacat bawaan". ${ }^{1}$ Artinya, Undang Undang Dasar 1945 hasil amendemen masih banyak mengandung kelemahan. Kelemahankelemahan itu paling ekstrim ditunjukkan oleh Dewan Perwakilan Daerah (DPD). Tak tanggung-tanggung, baru empat tahun amendemen UUD 1945, tepatnya 2006 lalu, anggota-anggota DPD yang juga merupakan bagian dari keanggotaan MPR meminta amendemen kelima. Pada waktu itu, apa yang disuarakan oleh DPD ini kurang atau bahkan sama sekali tidak mendapat respon dari anggota-anggota MPR lainnya, yaitu anggota-anggota DPR. Hal ini dikarenakan proposal yang dibawa DPD itu hanyalah berkutip pada persoalan hak konstitusionalnya sebagai lembaga utama negara. UUD 1945 hasil amendemen tidak memberikan kewenangan legislasi yang seutuhnya kepada DPD.² UUD 1945 tidak melibatkan DPD dalam tahapan persetujuan yang merupakan tahapan yang paling menentukan dalam fungsi legislasi apakah sebuah rancangan undang-undang itu menjadi sebuah undang-undang atau tidak. DPD hanya dilibatkan dalam tahapan pengusulan dan pembahasan seperti halnya juga ditegaskan di dalam Putusan Mahkamah Konstitusi Nomor 92/PUU-X/2012 tentang Pengujian Undang-Undang Nomor 27 Tahun 2009 tentang MPR, DPR, DPD, dan DPRD dan Undang-Undang Nomor 12 Tahun 2011 tentang Pembentukan Peraturan Perundang-Undangan.

Mencermati aturan main di dalam proses legislasi di atas, menurut hemat Penulis, MPR periode 1999-2004 telah melakukan kasalahan yang mendasar. Bagaimana tidak, DPD secara teoretis merupakan lembaga legislatif di samping DPR, namun fungsi utama lembaga legislatif sebagai pembuat undang-undang itu sendiri DPD tidak ada. Ironisnya, Presiden sebagai lembaga eksekutif malahan diberikan fungsi utama lembaga legislatif itu.

1 Lebih lanjut lihat HAS Natabaya, "Cacat Bawaan” Hasil Amendemen (Perubahan) UUD 1945 Tahun 1999-2002”, artikel dalam Jurnal Legislasi Indonesia, Vol. 7 No. 1, Maret 2010, hlm. 143-162.

${ }^{2}$ Denny Indrayana mengatakan bahwa DPD telah lahir, namun belum sepenuhnya hadir. Keberadaan DPD ini hampir sama dengan ketiadaannya. DPD dianggapnya antara "ada" dan "tiada". Lebih lanjut lihat Denny Indrayana, "Refleksi Lima Tahun Amendemen UUD 1945 Menyempurnakan Konstitusi, Memberantas Korupsi”, artikel dalam Jurnal Legislasi Indonesia, Jakarta, Vol. 4 No. 3, September 2007, hlm.79. 
Karena tidak mendapat respon dari anggota-anggota DPR, anggota-anggota DPD pun tak kehabisan akal. Anggota-anggota DPD membawa usulan-usulan yang lebih komprehensif termasuk dengan naskah akademiknya. Adapun pokokpokok usul Amendemen Kelima itu adalah sebagai berikut: ${ }^{3}$

1. Penguatan sistem presidensial;

2. Penguatan lembaga perwakilan;

3. Pengutan otonomi daerah;

4. Calon presiden perorangan;

5. Pemilihan nasional dan pemilihan lokal;

6. Forum previlegiatum bagi pejabat publik;

7. Optimalisasi peran Mahkamah Konstitusi (MK);

8. Penambahan pasal Hak Asasi Manusia (HAM);

9. Komisi negara; dan

10. Penajaman bab tentang pendidikan dan perekonomian nasional.

Sepuluh pokok usulan DPD di atas, kalau dibaca uraiannya lebih lanjut, UUD 1945 hari ini sudah seharusnya dilakukan amendemen lanjutan. Karena itulah sejumlah anggota DPR periode 2004-2009 menyambut baik usulan DPD itu. Hal ini dibuktikan dengan sejumlah tanda tangan mereka. ${ }^{4}$

Ironisnya, berjalannya waktu, sejumlah anggota DPR yang tadinya memberikan respon positif malahan menarik dukungannya. Alasannya adalah karena berdekatan dengan Pemilu 2009. Mereka bahkan juga mengatakan bahwa belum saatnya UUD 1945 diamendemen. ${ }^{5}$

Kendatipun demikian, semangat amendemen yang bergelora dari DPD periode 2004-2009 itu, tetap saja dilanjutkan oleh anggota-anggota DPD periode berikutnya, periode 2009-2014. Bahkan sampai saat ini, anggota-anggota DPD periode 2014-2019 juga tetap mengusung amendemen lanjutan terhadap UUD 1945. Hal ini bisa dilihat melalui sosialisasi-sosialisasi mereka terutama di perguruan tinggi.

Tak hanya anggota-anggota DPD, MK sebagai penafsir akhir konstitusi juga menyadari kelemahan-kelemahan UUD 1945 hasil amendemen itu. Salah satunya

\footnotetext{
3 Tim Penyusun Dewan Perwakilan Daerah, Info Memo, Perubaban Kelima Undang-Undang Dasar Negara Republik Indonesia Tabun 1945, Kepaniteraan dan Sekretariat Jenderal Dewan Perwakilan Daerah Republik Indonesia, Jakarta, 2011, hlm. 11-22.

${ }^{4}$ Lihat Ibid., hlm. 5-8.

${ }^{5}$ Ibid.
} 
yang disoroti MK itu adalah kewenangan MK untuk mengadili gugatan keluhan konstitusinal (constitutional complaint). ${ }^{6}$

Beberapa uraian di atas, menjelaskan gambaran bahwa Undang-Undang Dasar 1945 hasil amendemen saat ini memang masih mengandung banyak kekurangan, yang bahkan telah disadari oleh institusi negara. Keadaan ini juga menuntut adanya amendemen lanjutan untuk menutupi kekurangan-kekurangan yang ada. Sedangkan pada saat yang bersamaan, amendemen UUD 1945 sangat sulit sekali untuk dicapai karena kendala aspek formal prosedural. Maka dari itu, terlihatlah bagaimana sulitnya mewujudkan UUD 1945 sebagai konstitusi hidup. Konstitusi hidup yang peneliti maksud adalah konstitusi yang mempu mengikuti perkembangan dan kebutuhan zaman.

\section{Rumusan Masalah}

Di dalam penelitian ini peneliti mengajukan 2 rumusan masalah, yaitu: Pertama, faktor apa saja yang menghambat amendemen kelima UUD 1945? Kedua, bagaimana upaya mewujudkan UUD 1945 sebagai konstitusi hidup?

\section{Tujuan Penelitian}

Penelitian ini bertujuan untuk mengkaji faktor penghambat amendemen kelima UUD 1945 di saat beberapa ketentuan yang ada di dalamnya tidak lagi mampu menjawab tantangan zaman. Di samping itu, penelitian ini juga untuk mengkaji upaya mewujudkan UUD 1945 sebagai konstitusi hidup di saat sulitnya untuk mewujudkan perubahan formal melalui amendemen kelima UUD 1945.

\section{Metode Penelitian}

Dilihat dari jenisnya, penelitian ini adalah penelitian hukum normatif. Sumber data yang digunakan adalah data sekunder yang terdiri dari bahan hukum primer dan bahan hukum sekunder yang berfungsi memberikan penjelasan

${ }^{6}$ Keluhan konstitusional (constitutional complaint) dapat diterjemahkan sebagai salah satu bentuk upaya hukum perlindungan hak-hak konstitusional warga negara melalui sebuah pengaduan atau gugatan yang diajukan oleh perseorangan ke MK terhadap perbuatan atau kelalaian suatu lembaga publik yang mengakibatkan terlanggarnya hak-hak dasar atau hak-hak konstitusional orang yang bersangkutan. Lihat Tim Penyusun Refleksi Kinerja Mahkamah Konstitusi Republik Indonesia 2009, Mengawal Demokrasi Menegakkean Keadilan Substantif, Refleksi Kinerja MK 2009, Kepaniteraan dan Sekretariat Jenderal Mahkamah Konstitusi Republik Indonesia, Jakarta, 2010, hlm. 54-55. 
mengenai bahan hukum primer. Setelah data di dalam penelitian ini terhimpun, lebih lanjut Peneliti melakukan analisis yang merupakan langkah terakhir dalam sebuah kegiatan penelitian. Dalam analisis data, Peneliti menggunakan pendekatan peraturan perundang-undangan, pendekatan konsep, pendekatan politik, dan pendekatan sejarah.

\section{Hasil Penelitian dan Pembahasan}

\section{Faktor Penghambat Amendemen Kelima UUD 1945}

Amendemen UUD bukan hanya mengandung aspek hukum, namun juga aspek politik. ${ }^{7}$ Karena itu, sebaik apapun proposal amendemen yang diajukan oleh anggota-anggota MPR dari anggota-anggota DPD, bilamana aspek hukumnya dalam hal ini prosedur perubahan yang terlalu rigid, tidak praktis, atau hampir "mustahil" untuk dilakukan perubahan, maupun aspek politik dalam hal tidak didukung oleh kekuatan mayoritas, begitu juga momentum yang luar biasa, maka proposal amendemen tersebut hanyalah sebatas hitam di atas kertas putih yang tak pernah berlaku. Inilah yang terjadi saat ini dengan proposal yang diajukan oleh anggota-anggota MPR dari anggota-anggota DPD tersebut.

\section{Prosedur Perubahan UUD 1945 yang Terlalu Rigid}

Perubahan UUD perlu melalui prosedur-prosedur tertentu bukan untuk mempermudah perubahan, melainkan sebaliknya untuk mempersulit perubahan atau membatasi perubahan. Adapun sasaran yang hendak dituju melalui berbagai prosedur perubahan itu berdasarkan pendapat K.C. Wheare sebagaimana dikutip oleh Ellydar Chaidir dan Sudi Fahmi, yaitu: ${ }^{8}$

1. Supaya perubahan dilakukan dengan pertimbangan masak dan secara sadar, bukan secara serampangan.

2. Supaya rakyat mempunyai kesempatan memberikan pendapat sebelum perubahan benar-benar dilakukan.

3. Supaya kekuasaan negara bagian dan pemerintah pusat di negara federal tidak diubah secara sepihak.

4. Supaya hak-hak individu masyarakat seperti kaum minoritas dari segi agama, bahasa dan kebudayaan terjamin.

\footnotetext{
${ }^{7}$ Sri Soemantri, Prosedur dan Sistem Perubahan Konstitusi, PT. Alumni, Bandung, 2006, hlm. 179.

${ }^{8}$ Ellydar Chaidir \& Sudi Fahmi, Hukum Perbandingan Konstitusi, Total Media, Yogyakarta, 2010, hlm. 53.
} 
Pandangan K.C. Wheare di atas, Penulis mengamininya. Sebab konstitusi berisikan norma dasar, sehingga ketika terlalu mudah dalam perubahan akan berpengaruh besar terhadap peraturan perundang-undangan di bawahnya. Tentu saja, peraturan perundang-undangan di bawah konstitusi tersebut haruslah disesuaikan kembali dengan norma baru konstitusi itu.

Pasal 37 UUD 1945 menyebutkan bahwa:

1. Usul perubahan pasal-pasal Undang-Undang Dasar dapat diagendakan dalam sidang Majelis Permusyawaratan Rakyat apabila diajukan oleh sekurang-kurangnya 1/3 dari jumlah anggota Majelis Permusyawaratan Rakyat.

2. Setiap usul perubahan pasal-pasal Undang-Undang Dasar diajukan secara tertulis dan ditunjukkan dengan jelas bagian yang diusulkan untuk diubah beserta alasannya.

3. Untuk mengubah pasal-pasal Undang-Undang Dasar, Sidang Majelis Permusyawaratan Rakyat dihadiri oleh sekurang-kurangnya 2/3 dari jumlah anggota Majelis Permusyawaratan Rakyat.

4. Putusan untuk mengubah pasal-pasal Undang-Undang Dasar dilakukan dengan persetujuan sekurang-kurangnya 50 persen ditambah 1 anggota dari seluruh anggota Majelis Permusyawaratan Rakyat.

5. Khusus mengenai bentuk Negara Kesatuan Republik Indonesia tidak dapat dilakukan perubahan.

Mencermati secara seksama prosedur amendemen UUD 1945 di dalam Pasal 37 UUD 1945 di atas, bukan sekedar agar UUD 1945 tidak terlalu mudah untuk diamendemen (rigid), namun menurut hemat penulis adalah "menolak" untuk dilakukan perubahan (over rigid).

Oleh karena itu, wajar saja amendemen kelima yang diwacanakan oleh anggota-anggota MPR dari anggota-anggota DPD masih saja tetap menjadi wacana. Sebab dari sisi jumlah keanggotaan, anggota-anggota MPR dari anggotaanggota DPD tidak mencukupi syarat untuk dilakukan amendemen konstitusi. Jangankan sampai tahapan pembahasan atau persetujuan, tahapan usulan saja anggota-anggota MPR dari anggota-anggota DPD pun diganjal oleh prosedur formal Pasal 37 UUD 1945 tersebut. Untuk mengusulkan perubahan, disyarakatkan 1/3 dari jumlah anggota MPR. Karena jumlah anggota MPR periode ini adalah 692, berarti untuk usulan perubahan dibutuhkan 232 anggota MPR, sedangkan jumlah anggota DPD hanyalah 132, dan selebihnya 560 adalah anggota DPR. Berikut ini 
grafik jumlah keanggotaan MPR periode 2014-2019 dan tahapan amendemen UUD 1945 dari tahapan usulan sampai dengan persetujuan.

\section{Tidak Didukung oleh Kekuatan Mayoritas}

Anggota-anggota MPR dari anggota-anggota DPD membutuhkan dukungan mayoritas anggota-anggota DPR yang notabenenya juga merupakan anggota MPR. Pasal 2 ayat (1) UUD 1945 menyebutkan bahwa, "Majelis Permusyawaratan Rakyat terdiri atas anggota-anggota Dewan Perwakilan Rakyat, dan anggota Dewan Perwakilan Daerah yang dipilih melalui pemilihan umum dan diatur lebih lanjut dengan undang-undang". Namun, sayangnya anggota-anggota MPR dari anggota-anggota DPR tidak mendukungnya.

Penolakan anggota-anggota MPR dari anggota-anggota DPR akan amendemen kelima sesungguhnya lebih dalam rangka menjaga kewenangan yang begitu mapan secara konstitusional yang mereka miliki di bidang legislasi. Bagaimana tidak, di dalam Pasal 20 ayat (1) UUD 1945 dititahkan bahwa, "Dewan Perwakilan Rakyat memegang kekuasaan membentuk undang-undang". Sedangkan proposal yang diajukan oleh anggota-anggota MPR dari anggota-anggota DPD salah satunya adalah penguatan DPD di bidang legislasi. Tidak seperti selama ini, DPD hanya dilibatkan dalam tahapan usulan dan pembahasan, tidak dalam tahapan persetujuan. Padahal, tahapan persetujuan adalah tahapan yang paling menentukan atau krusial di bidang legislasi.

Keberadaan DPD selama ini menunjukkan bahwa DPD adalah institusi yang tidak lazim dalam praktik sistem bikameral. ${ }^{9}$ Ketidaklaziman tersebut menurut Stephen Sherlock, peneliti Australian National University karena DPD mengombinasikan kewenangan yang amat terbatas dengan legitimasi politik yang sangat tinggi (represents the odd combination of limited powers and high legitimacy). Itu sebabnya, meski memiliki fungsi representasi, tetapi DPD tak bisa mengkonkretkannya, baik secara individual maupun institusional. ${ }^{10}$

\footnotetext{
${ }_{9}$ Indonesia tidak dapat dikatakan menganut sistem bicameral (siatem dua kamar). Di samping DPR dan DPD, juga ada MPR. Ketiga lembaga tersebut punya fungsi dan wewenang yang berbeda satu dengan yang lainnya. lebih tepatnya, Indonesia menganut sistem trikameral (tiga kamar).

${ }^{10}$ Fajar L. Soeroso, “Land Mark Decision Perkara DPD”, artikel dalam Majalab Konstitusi, Nomor 74, April 2013, hlm. 10.
} 
Pada praktik legislasi, DPD sering kali tersudut dalam subordinasi DPR. Tak terhitung berapa rancangan undang-undang disampaikan DPD kepada DPR tetapi nihil tindak lanjut. Sudah banyak rancangan undang-undang yang diajukan DPD, lalu 'dicaplok' menjadi rancangan undang-undang usulan DPR. ${ }^{11}$ Begitu sering DPD tidak dilibatkan sama sekali dalam pembahasan rancangan undang-undang. Bahkan pernah, dalam suatu pembahasan rancangan undang-undang, DPD diundang DPR untuk memberikan pandangan. Akan tetapi, setelah menyampaikan pandangan, rapat diskors untuk mempersilahkan DPD meninggalkan ruangan rapat. Hal itu tak berarti lain kecuali kewenangan DPD yang lemah dalam legislasi. ${ }^{12}$ Padahal menurut UUD 1945, DPD ikut dalam tahapan usulan dan pembahasan.

Kalau Anggota DPR menanggapi proposal amandemen kelima itu dengan menyatakan belum saatnya untuk amandemen lanjutan, sesungguhnya itu adalah bentuk penolakan secara tidak langsung. Perlakuan DPR terhadap DPD selama ini cukup menjadi pertanda bahwa DPR tidak menerima jika DPD punya kewenangan yang full di bidang legislasi sepertinya DPR dan Presiden. Jangankan legislasi full, DPD punya fungsi legislasi semu saja seringkali digeragoti oleh DPR. Hal ini jelas sekali terlihat di dalam Undang-Undang Nomor Nomor 27 Tahun 2009 tentang MPR, DPR, DPD, dan DPRD, Undang-Undang Nomor 12 Tahun 2011 tentang Pembentukan Peraturan Perundang-undangan, dan Undang-Undang Nomor 17 Tahun 2014 tentang MPR, DPR, DPD, dan DPRD yang kemudian diluruskan oleh Putusan MK Nomor 92/PUU-X/2012 dan Putusan MK Nomor 79/PUU-XII/2014.

Kendatipun demikian, tetap saja kewenangan legislasi DPD tidak setara dengan DPR. Sebab, 2 putusan MK tersebut hanyalah mengembalikan kewenangan DPD sesuai dengan yang telah diamanatkan oleh UUD 1945, yaitu DPD ikut serta dalam hal usulan dan pembahasan,13 namun tidak dalam hal persetujuan yang merupakan puncak kewenangan legislasi sebuah lembaga.

${ }^{11} \mathrm{Hal}$ tersebut dibuktikan dengan fakta bahwa dari 247 RUU dalam daftar RUU Prolegnas 2010-2014, tidak ada satu pun RUU yang dinyatakan sebagai RUU yang berasal dari DPD. Padahal, sejak 2010, DPD telah secara berkala mengajukan usulan untuk Program Prolegnas kepada DPR. Lihat Putusan MK Nomor 92/PUU$\mathrm{X} / 2012$, hlm. 15.

${ }^{12}$ Fajar L. Soeroso, Loc. Cit.

${ }^{13}$ Lihat Pasal 22 D UUD 1945. Lihat juga Putusan MK Nomor 92/PUU-X/2012 dan Putusan MK Nomor 79/PUU-XII/2014. 


\section{Persoalan Momentum}

Sulit untuk membantah alasan ketiga ini. Nyatanya, momentum bagi proses pembuatan konstitusi justru kerap terjadi dalam masa-masa sulit dan penuh gejolak. Denny Indrayana mengutip pendapat Elster yang mengatakan bahwa kerapkali konstitusi ditulis “di saat-saat krisis yang membutuhkan tindakantindakan yang luar biasa dan dramatis". ${ }^{14}$

Lebih lanjut ada delapan peristiwa yang memicu pembuatan konstitusi, yaitu: ${ }^{15}$

1. Krisis Sosial dan ekonomi;

2. Revolusi;

3. Runtuhnya sebuah rezim;

4. Ketakutan akan runtuhnya sebuah rezim;

5. Kekalahan perang;

6. Rekonstruksi pasca perang;

7. Pembentukan sebuah negara baru; dan

8. Kemerdekaan dari kekuasaan kolonial.

Meyakini pandangan yang sama, Denny juga mengutip pendapat Mc Whinney bahwa tindakan-tindakan kodifikasi konstitusi yang berhasil nyaris selalu terjadi secara konsisten pada saat, atau segera setelah berlangsungnya masamasa sulit semacam itu, atau setelah masa-masa antusiasme publik yang diikuti oleh euforia publik. ${ }^{16}$

Di samping mengutip pandangan Elster dan Mc Whinney, Denny juga mengutip pendapat Bogdanor, yang mengatakan bahwa gejolak politik diperlukan untuk mereformasi sebuah konstitusi karena gejolak itu hadir sebagai tekanan yang menuntut perubahan konstitusi ketika konstitusi suatu negara tidak lagi sebangun-sejalan dengan nilai-nilai sosial. ${ }^{17}$

Mencermati berapa pandangan ahli di atas, penulis mengamininya. Amendemen pertama, kedua, ketiga, dan keempat dimulai dari 1999-2002 tersebut tidak akan terjadi manakala tidak didukung oleh momentum itu terutama momentum krisis ekonomi dan momentum runtuhnya rezim Soeharto 21 Mei 1998 itu.

14 Denny Indrayana, Amendemen UUD 1945 Antara Mitos dan Pembongkaran, PT. Mizan Pustaka, Jakarta, 2007, hlm. 79 .

15 Ibid., hlm. 79-80.

${ }^{16}$ Ibid.

${ }^{17}$ Ibid. 
Bandingkan dengan saat ini ketika DPD mengusulkan amendemen kelima. Menurut hemat penulis, dari delapan momentum perubahan konstitusi yang dikutip oleh Denny Indrayana dari Elster tersebut, tidak ada satupun yang mengena. Karena itu wajar saja proposal amendemen kelima DPD itu juga belum terrealiasasi kendatipun secara hukum amendemen itu dibenarkan dan secara akademikpun sudah seharusnya UUD 1945 diamendemen untuk kelima kalinya.

\section{Upaya Mewujudkan UUD 1945 sebagai Konstitusi Hidup}

Untuk menjamin agar substansi UUD atau konstitusi tetap hidup atau dapat menghadapi ketertinggalan, setiap UUD mengatur cara perubahan (amendemen). Dalam praktik perubahan formal tidak lagi dipandang satu-satunya cara menyesuaikan atau cara menghidupkan UUD. ${ }^{18}$

Amendemen senantiasa diiringi perdebatan yang panjang dan kompleks, baik dari segi politik, maupun ilmiah. Selain itu, amendemen acapkali melalui tata cara yang kompleks. Semuanya memakan waktu lama. Ada kemungkinan, ketika amendemen disahkan, sudah ada situasi baru dan tuntutan baru. ${ }^{19}$

Pada praktiknya, ada berbagai cara yang lebih praktis untuk mewujudkan konstitusi hidup, yaitu:

\section{Melalui Undang-Undang}

Betapa banyak undang-undang yang dibuat untuk melaksanakan UUD. Hampir semua undang-undang adalah semata-mata hasil rekayasa pembentuk undang-undang, bukan karena petunjuk UUD. ${ }^{20}$ Di Indonesia, hal ini dibenarkan Pasal 10 ayat (1) dan (2) Undang-Undang Nomor 12 Tahun 2011 tentang Pembentukan Peraturan Perundang-undangan menyebutkan bahwa:21

(1) Materi muatan yang harus diatur dengan undang-undang berisi:

a. pengaturan lebih lanjut mengenai ketentuan Undang-Undang Dasar Negara Republik Indonesia Tahun 1945;

b. perintah suatu Undang-Undang untuk diatur dengan Undang-Undang;

c. pengesahan perjanjian internasional tertentu;

\footnotetext{
${ }^{18}$ Bagir Manan dan Susi Dwi Harijanti, Memahami Konstitusi, Makna dan Aktualisasi, PT Raja Grafindo Persada, Jakarta, 2014, hlm. 133.

${ }^{19}$ Ibid.

${ }^{20}$ Ibid., hlm. 133-134.

21 Pasal 10 ayat (1) dan (2) Undang-Undang Nomor 12 Tahun 2011 tentang Pembentukan Peraturan Perundang-undangan.
} 
d. tindak lanjut atas putusan Mahkamah Konstitusi; dan/atau

e. pemenuhan kebutuhan hukum dalam masyarakat.

(2) Tindak lanjut atas putusan Mahkamah Konstitusi sebagaimana dimaksud pada ayat (1) huruf d dilakukan oleh DPR atau Presiden.

Karena itu, ukuran tidak terletak pada bunyi UUD melainkan maksud atau tujuan UUD. Bahkan, tak jarang undang-undang langsung didasarkan pada dasardasar fundamental negara, bukan substansi UUD. Acapkali untuk tujuan suatu politik, tujuan ekonomi, tujuan sosial, UUD digunakan dengan cara-cara yang berbeda dengan bunyi UUD. Di Amerika Serikat pernah ada kasus yang disebut dengan "baby boom". Undang-undang yang mengatur sewa-menyewa rumah atau harga rumah dibuat atas dasar "war power". Selain secara harfiah ganjil, pada saat itu tidak ada perang atau tidak dalam situasi perang. Undang-undang ini dibenarkan MA. ${ }^{22}$

Selama Orde Baru, UUD 1945 secara efektif sudah diubah beberapa kali. Tap MPR dan undang-undang tentang Referendum, yang mengubah prosedur perubahan adalah contoh "perubahan diam-diam". Mohammad Fajrul Falaakh berpandangan, contoh lain perubahan diam-diam adalah terkait dengan perluasan definisi “golongan-golongan" yang menjadi anggota MPR mencakup pula militer, campur tangan eksekutif terhadap independensi yudikatif melalui klaim otoritas Soeharto untuk mengangkat Ketua dan Wakil Ketua MA, tata cara perubahan UUD 1945.23 Yusuf dan Basalim juga menegaskan bahwa diperluasnya definisi militer Indonesia, hingga mencakup Polri, adalah perubahan diam-diam terhadap Pasal 10 UUD 1945 yang membatasi definisi militer hanya untuk menyebut Angkatan Darat, Angkatan Laut, dan Angkatan Udara. ${ }^{24}$

Saat ini misalkan, mengenai wewenang MK dalam mengadili sengketa pemilihan kepala daerah (pilkada). Berdasarkan konstitusi, Pasal 24C UUD 1945, salah satu kewenangan MK adalah mengadili sengketa hasil pemilihan umum (pemilu), bukan sengketa pilkada. Pemilu dan pilkada adalah dua rezim yang berbeda.

${ }^{22}$ Ibid., hlm. 134.

${ }^{23}$ Saldi Isra, "Perubahan Undang-Undang Dasar 1945 dan Implikasinya bagi Sistem Ketatanegaraan Indonesia", artikel dalam Jurnal Respublika, Pekanbaru, Nomor 2 Volume 3, Oktober 2002, hlm. 165.

${ }^{24}$ Denny Indrayana, Op. Cit., hlm. 164. 
Pasal 22E ayat (2) UUD 1945 menyebutkan bahwa, "Pemilihan umum diselenggarakan untuk memilih anggota Dewan Perwakilan Rakyat, Dewan Perwakilan Daerah, Presiden dan wakil presiden dan Dewan Perwakilan Rakyat Daerah". Di dalam pasal ini, sama sekali tidak disebutkan pilkada, apakah itu untuk calon gubernur, bupati, maupun walikota. Jadi MK hanyalah mengadili sengketa hasil pemilu bagi peserta atau calon anggota DPR, DPD, Presiden dan Wakil Presiden, serta DPRD. Sedangkan mengenai pilkada diatur di dalam Pasal 18 ayat (4) UUD 1945 yaitu, "Gubernur, Bupati, dan Walikota masing-masing sebagai kepala pemerintah daerah provinsi, kabupaten dan kota dipilih secara demokratis". Kendatipun UUD 1945 menyatakan demikian, namun Undang-Undang Nomor 22 Tahun 2007 tentang Penyelenggara Pemilihan Umum dan Undang-Undang Nomor 12 Tahun 2008 tentang Perubahan Kedua Atas Undang-Undang Nomor 32 Tahun 2004 tentang Pemerintahan Daerah ${ }^{25}$ menempatkan pilkada ke dalam rezim pemilu, sehingga hasil sengkata pilkada menjadi objek dari kewenangan MK.

Menariknya, dalam perjalanan waktu, MK menyatakan tidak berwenang untuk mengadili sengketa hasil Pilkada. Alasan utamanya adalah bahwa pilkada bukanlah rezim pemilu, tapi rezim pemerintahan daerah. ${ }^{26}$ Kendatipun demikian, DPR dan Presiden melalui revisi Undang-Undang Nomor 1 Tahun 2015 tentang Penetapan Peraturan Pemerintah Pengganti Undang-Undang 1 Nomor 2014 tentang Pemilihan Gubernur, Bupati, dan Walikota, menempatkan kembali MK sebagai lembaga pengadil dalam mengadili sengkata hasil pemilihan gubernur, bupati, dan walikota (pilkada).

\section{Melalui Interpretasi Hakim Konstitusi}

Selama ini, di Indonesia, interpretasi hakim yang mengubah UUD 1945 juga beberapa kali terjadi. Contoh yang paling fenomenal adalah ketika MK di dalam Putusan Nomor 138/PUU-VII/2009 tentang Pengujian Peraturan Pemerintah Penganti Undang-Undang Nomor 4 Tahun 2009 tentang Perubahan Atas UndangUndang Nomor 30 Tahun 2002 tentang Komisi Pemberantasan Tindak Pidana

\footnotetext{
${ }^{25}$ Saat ini, Undang-Undang Nomor 32 Tahun 2004 sudah diganti oleh Undang-Undang Nomor 23 Tahun 2014.

${ }^{26}$ Lihat Putusan MK Nomor 97/PUU-XI/2013 mengenai Pengujian Undang-Undang Nomor 12 Tahun 2008 tentang Pemerintahan Daerah dan Undang-Undang Nomor 48 Tahun 2009 tentang Kekuasaan Kehakiman.
} 
Korupsi menyatakan berwenang untuk menguji konstitusionalitas peraturan pemerintah pengganti undang-undang. ${ }^{27}$ Padahal, Pasal 24C ayat (1) UUD 1945 menyatakan bahwa "Mahkamah Konstitusi berwenang mengadili pada tingkat pertama dan terakhir yang putusannya bersifat final untuk menguji undang-undang terhadap undang-undang dasar...". Jadi, sama sekali Pasal 24C ayat (1) tersebut tidak menyebutkan peraturan pemerintah pengganti undang-undang.

Adanya putusan MK ini, secara tidak langsung telah terjadi perubahan informal terhadap UUD 1945. Memang secara teks tidak ada perubahan, namun dari sisi makna sesungguhnya Pasal 24C ayat (1) UUD 1945 tersebut telah mengalami perubahan yang sangat mendasar. Meskipun undang-undang dan peraturan pemerintah pengganti undang-undang dari sisi muatannya sama, namun dari sisi formalitas adalah dua hal yang berbeda. Dengan demikian, Pasal 24C ayat (1) UUD 1945 berubah makna menjadi "Mahkamah Konstitusi berwenang mengadili pada tingkat pertama dan terakhir yang putusannya bersifat final untuk menguji undang-undang/peraturan pemerintah pengganti undang-undang terhadap undangundang dasar...".

Adanya perubahan UUD 1945 secara informal tersebut tidak terlepas dari budaya konstitusi hakim yang melatarbelakangi munculnya penafsiran yang merubah makna teks. Hal ini menunjukkan bahwa MK dapat menentukan ke arah manakah UUD 1945 hendak dijalankan. ${ }^{28}$

Karena itu, mengingat salah satu materi proposal amendemen kelima adalah penguatan fungsi legislasi DPD, menurut hemat penulis, seharusnya MK “dapat” menghidupkan Pasal 22C dan D UUD 1945 ketika menguji konstitusionalitas Undang-Undang Nomor Nomor 27 Tahun 2009 tentang MPR, DPR, DPD, dan DPRD dan Undang-Undang Nomor 12 Tahun 2011 tentang Pembentukan Peraturan Perundang-Undangan, ${ }^{29}$ serta Undang-Undang Nomor 17 Tahun 2014

${ }^{27}$ Pengujian Perppu oleh MK ini pun kemudian menimbulkan pro dan kontra. Lihat dalam Ni'matul Huda, "Pengujian Perpu Oleh Mahkamah Konstitusi", artikel dalam Jurnal Konstitusi, Vol. 7 No. 5, Oktober 2010. Baca juga Iskandar Muda, "Pro-Kontra dan Prospektif Kewenangan Uji Konstitusionalitas Perpu”, artikel dalam Jurnal Konstitusi, Vol. 10, No. 1, Maret 2013. Juga Ibnu Sina Chandranegara, "Pengujian Perppu Terkait Sengketa Kewenangan Konstitusional Antar-Lembaga Negara (Kajian Atas Putusan MK Nomor 138/PUU-VII/2009), artikel dalam Jurnal Yudisial, Vol. 5 No. 1, April 2012.

${ }^{28}$ Khairul Umam, Teori dan Metode Perubahan, Undang-Undang Dasar 1945 Melalui Tafsir Konstitusi Perspektif Budaya Konstitusi, Thafamedia, Yogyakarta, 2016, hlm. 7.

${ }^{29}$ Putusan Nomor 92/PUU-X/2012 Mengenai Pengujian Undang-undang Nomor 27 Tahun 2009 dan Undang-undang Nomor 12 Tahun 2011. 
yang menggantikan Undang-Undang Nomor 27 Tahun 2009.30 Sayangnya, MK tidak memanfaatkan momentum itu untuk menyatakan bahwa DPD tidak hanya dilibatkan dalam tahapan usulan dan pembahasan, tetapi juga dalam tahapan persetujuan yang merupakan puncak fungsi legislasi. Andai kata demikian, sesungguhnya MK telah meluruskan kekeliruan yang telah dilakukan oleh anggota MPR periode 1999-2004 yang lalu.

\section{Melalui Konvensi atau Praktik Ketatanegaraan}

Secara dogmatik, praktik ketatanegaraan bukan hanya dapat memberikan makna baru, bahkan dapat menyampingkan substansi atau kaidah UUD. Praktik ketatanegaraan ini tidak menjadi soal ketika dibarengi dengan tradisi atau keajegan sistem ketatanegaraan. Ditinjau dari ajaran konstitusi, praktik ketatanegaraan dimaksudkan untuk memperkuat sendi-sendi konstitusi (berkonstitusi), seperti konstitusionalisme, prinsip negara hukum, dan demokrasi. Satu patokan yang tidak dapat dilewati adalah dasar-dasar fundamental UUD atau bernegara. Dalam konteks Indonesia, antara lain Pancasila. Dengan demikian, praktik ketatanegaraan yang dengan senagaja menyampingkan UUD dan dasar-dasar fundamental negara untuk sebuah kediktatoran atau kekuasaan otoriter, bukanlah praktik ketatanegaraan dalam makna konvensi. ${ }^{31}$

Di Indonesia, misalkan keluarnya Maklumat Nomor X tanggal 16 Oktober 1945 yang ditandatangani oleh Mohammad Hatta. Maklumat ini menetapkan bahwa: ${ }^{32}$

“Komite Nasional Pusat, sebelum terbentuknya Majaelis Permusyawaratan Rakyat dan Dewan Perwakilan Rakyat diserahi kekuasan legislatif dan ikut serta menetapkan garis-garis besar daripada haluan negara.

Bahwa pekerjaan Komite Nasional Pusat sehari-hari berhubung dengan gentingnya keadaan dijalankan oleh sebuah Badan Pekerja yang dipilih antara mereka serta bertanggung jawab kepada Komite Nasional Pusat".

Adanya maklumat ini, sesungguhnya telah mengubah dalam praktik UUD 1945 produk Badan Penyelidik Usaha Persiapan Kemerdekaan Indonesia itu. Sebab Aturan Tambahan UUD 1945 menyebutkan bahwa, "Sebelum Majelis

\footnotetext{
30 Putusan Nomor 79/PUU-XII/2014 Mengenai Pengujian Undang-Undang Nomor 27 Tahun 2009.

31 Bagir Manan dan Susi Dwi Harijanti, Op. Cit., hlm. 134-135.

32 Ni'matul Huda, Hukum Tata Negara Indonesia, PT Raja Grafindo Persada, Jakarta, 2008, hlm. 114.
} 
Permusyawaratan Rakyat, Dewan Perwakilan Rakyat dan Dewan Pertimbangan Agung dibentuk menurut Undang-Undang Dasar ini, segala kekuasaannya dijalankan oleh Presiden dengan bantuan sebuah Komite Nasional".

Adanya Maklumat Nomor $\mathrm{X}$ ini kemudian disusul dengan Maklumat Pemerintah 14 Nopember 1945. Maklumat ini juga mengubah UUD 1945 dalam praktiknya. Kalau semulanya kabinet atau para menteri bertanggung jawab kepada Presiden Soekarno, ketika keluar maklumat itu kabinet bertanggung jawab secara langsung kepada Perdana Menteri, yaitu Sutan Syahrir. Pasal 17 UUD 1945 menyebutkan bahwa: 1) Presiden dibantu oleh Menteri-menteri Negara. 2) Menteri-menteri itu diangkat dan diberhentikan oleh Presiden.

Beberapa contoh di masa lalu tersebut, menunjukkan bahwa telah terjadi perubahan terhadap beberapa pasal di dalam UUD 1945 tanpa perubahan formal yang diatur di dalam Pasal 37 UUD 1945. Inilah yang disebut perubahan UUD dengan cara istimewa, salah satunya adalah melalui konvensi ketatanegaraan yang juga mendapatkan pengakuan dari ahli-ahli hukum tata negara sebagai salah satu sumber hukum tata negara. Karena itu, perubahan UUD 1945 melalui konvensi ini mempunyai akar sejarah dalam konteks ketatanegaraan kita. Dalam hal-hal tertentu manusia lebih cepat perkembangannya dari pada hukum itu sendiri. Dan konvensi adalah salah satu cara praktis atau tidak kaku yang mampu mengimbangi perkembangan hukum dan manusia.

Berdasarkan penjelasan di atas menunjukkan bahwa untuk mewujudkan UUD 1945 sebagai konstitusi yang mampu memenuhi kebutuhan, dinamika dan perkembangan zaman, prosedur formal melalui cara amendemen bukanlah satusatunya jalan. Bahkan, perubahan non-formal dalam praktiknya lebih banyak terjadi daripada melalui prosedural formal yang dikenal dengan prosedur kaku itu. Secara teoripun hal ini dapat dibenarkan. George Jellinek membagi menjadi dua prosedur perubahan UUD, yaitu, pertama, melalui prosedur formal (verfassungsanderung) dan kedua, melalui cara-cara informal (verfassungswandlung). Perubahan formal adalah perubahan yang mekanismenya telah diatur di dalam 
konstitusi suatu negara sedangkan perubahan di luar ketentuan konstitusi disebut sebagai perubahan informal. ${ }^{33}$

K.C. Wheare menyatakan bahwa perubahan konstitusi ada 4 metode, yaitu: ${ }^{34}$

a. Some primary forces, yaitu perubahan karena terdapat kekuatan-kekuatan yang mampu menimbulkan perubahan konstitusi itu sendiri.

b. Formal amendment, yaitu perubahan konstitusi melalui proses yang ditentukan oleh konstitusi itu sendiri.

c. Judicial interpretation, yaitu perubahan konstitusi melalui penafsiran berdasarkan hukum.

d. Usage and convention, yaitu perubahan konstitusi melalui kebiasaan ketatanegaraan dan konvensi.

\section{Penutup}

Setelah melakukan penelitian dan menguraikan dua permasalahan dalam penelitian ini, maka dapat ditarik kesimpulan sebagai berikut:

1. Ada beberapa faktor penghambat amendemen kelima UUD 1945. Pertama, prosedur perubahan formal UUD 1945 yang terlalu rigid. Dalam hal usulan saja, diharuskan berasal dari minimal 1/3 dari anggota MPR. Sebagai pengusul, anggota DPD yang notabenenya juga adalah anggota MPR, hanyalah berisikan 132 orang. Artinya tidak mencapai $1 / 3$ anggota MPR yang seluruhnya berjumlah 692 orang. Kedua, tidak mendapatkan dukungan politik. Dalam hal ini adalah dukungan politik dari anggota-anggota DPR yang notabenenya juga sebagai anggota MPR. Anggota MPR yang berasal dari keanggotaan DPR lebih dari 2/3. Jadi, anggota-anggota DPD membutuhkan dukungan dari anggotaanggota DPR untuk meloloskan proposal amendemen itu. Ketiga, momentum yang tidak mendukung amendemen kelima. Amendemen tidak hanya persoalan substansi apa yang akan diubah, diganti, atau direvisi, namun yang lebih penting lagi adalah momentum. Secara umum, mulusnya amendemen di saat situasi sedang bergejolak terutama krisis ekonomi dan krisis politik tingkat tinggi sebagai dampak dari rezim yang otoriter seperti halnya amendemen 19992002 yang lalu. hlm. 80 .

${ }_{33}$ Jimly Asshiddiqie, Pokok-Pokok Hukum Tata Negara Indonesia, PT. Bhuana Ilmu Populer, Jakarta, 2008,

${ }^{34}$ K. C. Wheare, Konstitusi-Konstitusi Modern, Pustaka Eurika, Surabaya, 2003, hlm. 103. 
2. Ada beberapa upaya yang dapat dilakukan untuk mewujudkan UUD 1945 sebagai kontitusi hidup di saat sulitnya amendemen kelima UUD 1945. Pertama, melalui undang-undang. Kedua, melalui interpretasi hakim konstitusi. Ketiga, melalui konvensi ketatanegaraan. Cara-cara ini baik secara teori dan praktik dapat dibenarkan. Secara teori didasarkan pandangan K.C. Wheare, Geoge Jellinek, dan lainnya. Secara praktik, ketiga cara tersebut keberadaannya diakui sebagai bagian yang tak terpisahkan dari perjalanan ketatanegaraan Indonesia dari dulu hingga sekarang.

Saran-saran yang dapat direkomendasikan dalam penelitian ini dapat dirinci sebagai berikut:

1. Hendaknya anggota-anggota MPR yang berasal dari anggota-angota DPR memberikan dukungan kepada anggota-anggota MPR yang berasal dari anggota-anggota DPD untuk mewujudkan amendemen kelima. Tanpa dukungan itu, "mustahil" rasanya akan terwujudnya amendemen kelima UUD 1945 yang memang sudah waktunya untuk kembali diamendemen.

2. Hendaknya DPR dan Presiden dapat mewujudkan UUD 1945 sebagi konstitusi hidup melalui undang-undang. Begitu juga dengan hakim konstitusi melalui interpretasinya dapat memerankan perannya sebagai negarawan sejati yang tidak berhukum secara kaku dan legalistik-formalistik. Tak kalah pentingnya lagi adalah konvensi ketatanegaraan yang cerdas dari seorang Presiden.

\section{Daftar Pustaka}

\section{Buku}

Asshiddiqie, Jimly, Pokok-Pokok Hukum Tata Negara Indonesia, PT. Bhuana Ilmu Populer, Jakarta, 2008.

Chaidir, Ellydar \& Sudi Fahmi, Hukum Perbandingan Konstitusi, Total Media, Yogyakarta, 2010.

Huda, Ni'matul, Hukum Tata Negara Indonesia, PT. Raja Grafindo Persada, Jakarta, 2008.

Indrayana, Denny, Amendemen UUD 1945 Antara Mitos dan Pembongkaran, PT. Mizan Pustaka, Jakarta, 2007.

Khairul, Umam, Teori dan Metode Perubahan, Undang-undang Dasar 1945 Melalui Tafsir Konstitusi Perspektif Budaya Konstitusi, Thafamedia, Yogyakarta, 2016. 
Manan, Bagir dan Susi Dwi Harijanti, Memahami Konstitusi, Makna dan Aktualisasi, PT. Raja Grafindo Persada, Jakarta, 2014.

Marzuki, Peter Mahmud, Penelitian Hukum, Kencana, Jakarta, 2005.

Penyusun Dewan Perwakilan Daerah, Tim, Info Memo, Perubahan Kelima UndangUndang Dasar Negara Republik Indonesia Tahun 1945, Kepaniteraan dan Sekretariat Jenderal Dewan Perwakilan Daerah Republik Indonesia, Jakarta, 2011.

Soemantri, Sri, Prosedur dan Sistem Perubahan Konstitusi, PT. Alumni, Bandung, 2006.

Wheare, K. C., Konstitusi-Konstitusi Modern, Pustaka Eurika, Surabaya, 2003.

\section{Jurnal dan Makalah}

Huda, Ni'matul, "Pengujian Perpu Oleh Mahkamah Konstitusi”, Jurnal Konstitusi, Vol. 7 No. 5, Oktober 2010.

Indrayana, Denny, "Repleksi Lima Tahun Amendemen UUD 1945 Menyempurnakan Konstitusi, Memberantas Korupsi", Jurnal Legislasi Indonesia, Jakarta, Vol. 4 No. 3, September 2007.

Isra, Saldi, "Perubahan Undang-Undang Dasar 1945 dan Implikasinya bagi Sistem Ketatanegaraan Indonesia”, Jurnal Respublika FH. Unilak, Pekanbaru, Vol. 3 No. 2, Oktober 2002.

Muda, Iskandar, "Pro-Kontra dan Prospektif Kewenangan Uji Konstitusionalitas Perpu", Jurnal Konstitusi, Vol. 10 No. 1, Maret 2013.

Natabaya, HAS, “Cacat Bawaan” Hasil Amendemen (Perubahan) UUD 1945 Tahun 1999-2002", Jurnal Legislasi Indonesia, Jakarta, Vol. 7 No. 1, Maret 2010.

Sina Chandranegara, Ibnu, "Pengujian Perppu Terkait Sengketa Kewenangan Konstitusional Antar-Lembaga Negara (Kajian Atas Putusan MK Nomor 138/PUU-VII/2009)", Jurnal Yudisial, Vol. 5 No. 1, April 2012.

\section{Majalah}

L. Soeroso, Fajar, "Land Mark DecisionPerkara DPD”, Majalah Konstitusi, Nomor 74, April 2013.

\section{Peraturan Perundang-undangan}

Undang-Undang Dasar Negara Republik Indonesia Tahun 1945.

Undang-Undang Nomor 12 Tahun 2011 tentang Pembentukan Peraturan Perundang-undangan, Lembaran Negara Republik Indonesia Tahun 2011 Nomor 82.

\section{Putusan}

Putusan Nomor 138/PUU-VII/2009 tentang Pengujian Peraturan Pemerintah Penganti Undang-Undang Nomor 4 Tahun 2009 tentang Perubahan Atas 
Undang-Undang Nomor 30 Tahun 2002 tentang Komisi Pemberantasan Tindak Pidana Korupsi.

Putusan Nomor 92/PUU-X/2012 Mengenai Pengujian Undang-undang Nomor 27 Tahun 2009 tentang Majelis Permusyawaratan Rakyat, Dewan Perwakilan Rakyat, Dewan Perwakilan Daerah, dan Dewan Perwakilan Rakyat Daerahdan Undang-undang Nomor 12 Tahun 2011 tentang Pembentukan Peraturan Perundang-undangan.

Putusan Nomor 97/PUU-XI/2013Mengenai Pengujian Undang-Undang Nomor 12 Tahun 2008 tentang Pemerintahan Daerah dan Undang-Undang Nomor 48 Tahun 2009 tentang Kekuasaan Kehakiman.

Putusan Nomor 79/PUU-XII/2014 Mengenai Pengujian Undang-Undang Nomo 27 Tahun 2009 tentang Majelis Permusyawaratan Rakyat, Dewan Perwakilan Rakyat, Dewan Perwakilan Daerah, dan Dewan Perwakilan Rakyat Daerah. 